\title{
Inside the German Miracle. How trade unions shape the future of industrial working conditions
}

\author{
Gabi Schilling \\ SUniversity Duisburg-Essen; Essen, Germany \\ gabi.schilling@uni-due.de \\ Achim Vanselow \\ DGB-Bezirk NRW (German Trade Union Confederation, \\ Executive Board North Rhine-Westphalia) \\ achim.vanselow@dgb.de
}

\begin{abstract}
Low unemployment rates during the crisis and a quick recovery are the main characteristics of the "German miracle». The general role of social partners and in particular the role of trade unions in the affected sectors appear to be undervalued especially in macro-level economic analysis. This article provides an insight into the activities of the metalworkers union (IG Metall) in developing strategies for innovative and sustainable solutions to improve future production and working conditions.
\end{abstract}

Keywords: German Trade Union Confederation, Executive Board North RhineWestphalia, head of department for economic, structural and technology policy.

Resumen: Las bajas tasas de desempleo durante la crisis y la rápida recuperación son las principales características del «milagro alemán». El rol general de los actores sociales, $y$ en particular el rol de los sindicatos en los sectores afectados parecen estar infravalorados especialmente en el análisis a nivel macroeconómico. Este artículo proporciona una visión de las actividades del sindicato del metal (IG Metall) en el desarrollo de las estrategias para aportar soluciones innovadoras y sostenibles para mejorar la producción futura y las condiciones laborales.

Palabras clave: Confederación alemana de sindicatos, Consejo Ejecutivo Renania del Norte-Westfalia, Jefe del departamento de economía, politicas estructurales y tecnológicas. 


\section{Introduction}

Many international observers have been surprised by the positive development of the German economy in and after the crisis. Low unemployment rates during the crisis and a quick recovery of the affected parts of the economy are the main characteristics of this German miracle. Numerous analysts have tried to identify the reasons mainly at the macro level and to concentrate on fiscal policy and the export-led growth pattern (see for example OECD, 2010). The role of the labour market policy, especially the short-time working scheme, is taken into account at a general level. In the meantime other studies have analysed the labour market impacts and company level effects in greater detail (ILO, 2011). However, the German system of industrial relations in general and the role of trade unions in particular in the affected sectors appear to be rather undervalued in the analysis.

In this article we wish to provide an insight into the activities of the trade union IG Metall (the German union of metal workers) in a highly industrialized region in Germany (North Rhine-Westphalia), a centre of the German automotive and engineering industry, which was hit very hard by the economic crisis. Before and during this crisis the union developed a wide range of activities far beyond the scope of traditional trade union practice. The focus of these activities can be described as a pro-active approach, which aims to develop strategies for innovative and sustainable solutions for future production and working conditions in the metal industry. The German system of co-determination in the manufacturing sector usually offers a good lever to propel work-oriented high road strategies (institutionalized rights, tradition of conflict partnership). Works councils no longer wait for management decisions in order to react to them. Besides their protecting role they now ask management to seek sustainable long-term solutions for their company. To describe how this approach is working in practise this article will describe the methods and some of the results of the project 'competence\&innovation.nrw', which organized and created dialogues between works councils, scientists, union representatives and consultants in order to support works councils in negotiating on a par with management.

The article starts with a short overview about the crisis in the region of North Rhine-Westphalia (Part 1) and a few general remarks about trade unions and works councils in their new role as promoters of innovation. Innovations at the shop floor level are far from being free from contradiction and are highly influenced

1 The Project 'competence\&innovation' was funded by the Federal Ministry for Education and Research, and by the European Social Fund (ESF). It was implemented by the regional IG Metall organisations in BadenWuerttemberg and North Rhine-Westphalia, two of the seven regional organizations of this trade union (term: 01.01.2008-31.12.2011). The local organizations are the basic units in the overall structure. The information in this paper is mainly based on the North Rhine-Westphalia part of the project. 
by company interests. Innovative companies are generally innovative thanks to their employees. To ensure that employees' interests and rights are protected and that they also benefit from innovations, works councils have to act as drivers for innovation (Part 2). Subsequently the trade union campaign of IG Metall better not cheaper (in German: Besser statt billiger) is presented as an important framework for the project. It is a new approach that aims for trade unions and works councils to participate in the restructuring processes at the shop-floor level (Part 3). When the crisis started, the trade union decided to use a dual strategy at the shop-floor. Short-term oriented activities, like analysing the real impact of the crisis on the affected company together with works councils, and organizing the use of the short-time working scheme. To these activities, which aimed to protect jobs, were later added long-term oriented activities like checking the strategic concept of the company, their ability to innovate and similar issues. In this context the project competence $\mathcal{E}$ innovation.nrw promotes dialogue between works councils and science to enable swift application of scientific expertise to innovation-oriented actions of works councils (Part 4). The conclusion (Part 5) gives a short forecast of how the successful support of works councils in many companies will be integrated into a long term strategy for the union.

\section{The impact of the economic crisis in North Rhine- Westphalia}

The economic downturn in 2008 has hit the economy in North Rhine Westphalia (NRW) very hard because this region is the industrial heartland of Germany (MWEBWV 2011, VDMA 2010). With 20\% of the national GDP, NRW has the highest share of the 16 federal states in Germany. As an independent state in terms of GDP NRW would be number 17 in the world, immediately after the Netherlands. NRW is also the most populous and the most densely populated federal state in Germany with $17.9 \mathrm{~m}$. inhabitants. A sectoral change from industry to services has also taken place in NRW in recent decades, but industry and industry-related services remain very important. More than two million employees work in the production sector, the car and car supply industry (e.g. the plants of Opel and Ford), steel production (e.g. ThyssenKrupp), the chemical industry (e.g. Bayer) and mechanical engineering, just to mention the major industries. And it was precisely this part of the economy that suffered most in 2008 from the impact of the global crisis. In 2008 the demand for industrial products underwent a double-digit decrease. The foreign demand in 
the car industry collapsed (64\% fewer orders in March 2009 than March 2008) (arbeitgeber.nrw 2009:7). The business sections of the regional newspapers printed scenarios of an upcoming de-industrialization process, the end of 150 years of economic history in this region. Although this is only a very rough picture of the period of crisis (2008/2009) these few facts should help to give the reader an impression of the challenges that have to be managed by companies, trade unions and works councils.

The crisis reaction of IG Metall took place at different levels (national, regional). In this paper we take a closer look at the regional reactions. In the action field of collective bargaining policy the trade union focused on employment protection. The consequence of this strategy was that in the collective bargaining round of 2008 IG Metall for the first time abandoned demands for wage increases. In exchange the employers' organization committed themselves to keeping workers employed and to using the short-time working scheme.

The turbulent situation at the beginning and the climax of the crisis made it necessary to start activities to improve information and transparency. It was evident from the feedback of works councils that the crisis impacted quite differently on different regions, industries and companies. The form of the crisis at company level also differed widely: financial or liquidity problems, threat of insolvency or sharp decline in orders, just to mention a few, required different responses. To get an overview of the impact of the crisis from the works councils point of view the trade union carried out surveys and arranged conferences at company, industry and regional levels, which gave works councils the opportunity to understand the bigger picture of the impact on their industry and to exchange information and experiences with other works councils and trade unionists. The aim of these activities was to overcome the fragmentation and to start a collective process of understanding the effects of the crisis.

The concept was that works councils, supported by the union, should get more backing for action by getting information and organizing participation. They needed to clarify the possible course of action, develop their own assessment of the situation (rather than adopt the interpretation of the management), obtain external support from work-oriented consultants, exploit opportunities to question and evaluate the financial situation in the company and develop their own position. During this process works councils informed the employees and organized their participation.

This short-term reaction to the crisis was combined conceptually with a strategic perspective that aimed at the long-term development of the company. Many works councils had the experience of a management structure that was 
driven by numbers. This changed in the crisis because the retrospective information of quarterly figures was of little use in this situation. Instead, what could be done to save or even increase the number of jobs in the company? Could the future of the company be guaranteed by adjusting strategic fields and improving internal processes? In short: What was the company's future strategy? To support works councils, the trade union compiled manuals and check-lists, organized a network of work-oriented consultants and informed them about ways to finance these activities, including negotiations with the government about new funding opportunities.

To understand the reaction to the crisis of the IG Metall NRW we have to take a closer look at the modernization process of this union, which had already started in 2004. This modernization process is strongly connected with the idea that the trade union needs concepts and strategies to promote work-oriented high road strategies and has to organize participation processes and support for works councils and members at the shop-floor level.

\section{The changing role of works councils and unions: Promoters of innovation}

The capacity for innovation is often regarded as a key factor in Germany's ability to rise to challenges successfully. This has been even more important since the crisis. This capacity for innovation, market strength and position, flexibility, efficient resource management and qualified employees are critical factors for the good long term positioning of manufacturing businesses (Kleiner et alii, 2007). The successful adaptation to changing market conditions through work-oriented innovative strategies also benefits employees because, in addition to economic success, their employment security and the quality of their work improve.

Current findings indicate that works councils can play an important role in achieving innovation within companies (see Schwarz-Kocher et alii, 2011; Kriegesmann, Kley 2012). But the existence of a works council alone does not guarantee successful innovative processes. Innovation-oriented employee participation does not automatically lead to improved job quality. However, in spite of all ambivalences it is possible to show that the participation of works councils in innovative processes does have advantages and that they can maintain their position at the shop-floor level within the companies' operational framework (see Stracke, Nerdinger, 2010). From the trade-union point of view the innovation debate is often too narrow because it concentrates on advanced 
technologies in high tech industries and it easily ignores the actual situation, especially in companies with a lower $R \& D$ rate (which are the majority and represent the largest part of employment). However, works councils and trade unions are constantly discovering that there is a potential for improvement in many companies. Internal processes and work organisation have to be considered, as well as technical and product innovations. Seen in this light, innovation is not only defined by the volume of research and development or the number of patents, but also includes the in-plant requirements and conditions with a particular focus on the situation of the employees (for such a holistic concept of innovation, see e.g. Kirner et alii, 2010).

In the past the cooperation of engineers and well-trained skilled workers contributed to the strength of German industrial competitiveness but this has been continuously weakened (Bosch, 2009). In addition there are now several reasons for a shortage of highly skilled workers in the labour market. The focus on reducing employment costs, maximizing short-term profit, moving production to low wage countries and splitting up the workforce into temporary and permanent staff does not create a sustainable organisation of work and workforce. To achieve a sustainable future for industrial work in Germany there is a strong need for companies to create working conditions and the labour market to create employment. This helps to preserve and develop the individual capacity to work, enhances employees' wellbeing and provides new employment opportunities (see Lehndorff, 2003). Seen in this light, the well-known statement that man is the centre of innovation strategies leaves a bitter aftertaste. On the contrary many employees experienced continuous staff reductions, loss of employment security and work intensification in their industries a long time before the crisis. Employees who are afraid of losing their job are less productive and less capable of creating innovation. Management strategies exploiting cheap solutions, such as the intensive use of temporary work or threats of outsourcing, waste the human resource that are required to be successful in more and more competitive and unstable conditions. Research has shown that there is no one best way or panacea for the economic adjustment of companies. In fact various solutions have been adopted not only in different European countries but also in different regions and industries so there is room for manoeuvre (see e.g. Goudswaard et alii, 2009). As far as innovations in the workplace are concerned, the authors see three typical ways forward:

- The bigh road of innovation, which focuses on long-term solutions, employee retention and development and above all on internal functional flexibility. 
- The low road, which focuses on short-term cost cutting strategies and external flexibility, and

+ The do notbing road, which abstains from any substantial change.

From the employees point of view the high road strategy is to be favoured because it focuses on competitiveness and the quality of work. Long-term and sustainable companies prove their worth in the competition for quality, not price. Therefore, they need good human resource development. In addition to investment in plants and machinery and the development of innovative products they need to utilize and develop employee resources and the participation of the works council in innovative change processes. An important lesson to be learned from these and similar surveys is that there is no blueprint for bigh road solutions.

The German system of industrial relations offers a good framework to act as a corrective for company strategies which are not always rational. In the regulatory model, the collective interests of the employees, like wages and working conditions, are negotiated by comprehensive organisations representing employers and employees, while works councils represent employees' interests at company level and make sure that the collective agreements are enforced. However, market-driven development creates new problems but also new opportunities for trade union action to modernize work practises (see Iwer, Wagner, 2005: 113). In this respect, works councils can even produce locational advantages which are not limited to the legal regulations of labour relations. In recent years, works councils have been required to act as competent managers of crisis and promoters of change, as proven by research into German works councils (see Blume, Gerstlberger, 2007, Jirjahn, 2006). Works councils are tired of only being able to react to the new demands (and impertinences) of executive boards. They want to play a more active role in the design of working conditions and, in some cases, they have done so successfully. In September 2009 the trade union IG Metall interviewed 157 works councils about their role in crisis development and identified themes where there were conflicts of interests. The principal finding was that in companies where works councils were included in the development of future strategies the prospects of surviving the crisis were much better than in companies that did not include them and paid too little attention to strategic development.

Works councils know their companies and are familiar with the working conditions, and thus the basis for innovations. «By participating actively in working conditions supporting innovation, works councils can influence the company's treatment of innovation» (Kriegesmann et alii, 2010:76). At the same time it is evident that many employees and works councils do not use their 
expertise effectively. Works councils are mainly included in the familiar and legally required fields of action such as work organisation, personnel policy or in-plant social policy as Kriegesmann et alii (2010:73) have shown by analysing data from a survey of works councils (2008/2009). However, their participation is not limited to these areas. To a lesser degree they also participate in product and service innovations and in developing new markets. The researchers clearly indicate that works councils proactive involvement in the innovation process is by no means rare. Nowadays knowledge of the collective agreement and the Works Constitution Act is not enough to judge the effect of new corporate strategies on employees. One result of this on the shop-floor is to increase the pressure to be more professional in analysing problems brought about by the crisis and forcing management to find sustainable solutions for future challenges.

To prevent misunderstandings, it should be pointed out that works councils are not expected to take over the tasks or responsibilities neglected by management. The aim is to teach them how to judge early and systematically if the company is on a path which will guarantee the future and safeguard jobs or not. To do this works councils have to learn how to identify management strategies, even if they are not obvious, and their place within the corporate strategy. They also have to be able to detect misleading arguments advocating cuts in companies as the only possible solution.

The new challenge for works councils is to critically analyse the medium- and long-term consequences of management decisions against the background of the corporate strategy, to develop alternative solutions and to implement the better alternatives together with the employees (see Tietel, 2006).

The aim of the project competenceEinnovation is to support works councils in dealing with these demands. This project is embedded in the better not cheaper campaign policy of the trade union IG Metall in the German region North Rhine-Westphalia, which is outlined below.

\section{Better not cheaper: An innovative union strategy in and after crisis}

IG Metall is still one of the biggest trade unions in Europe in terms of membership and one of the most powerful single trade unions in Germany. It represents the interests of 2.26 million members (Lesch, 2010). Like many other trade unions, IG Metall had long suffered from decreasing membership. In 2008 this trend appeared to end ( $+14.6 \%$ compared to 2007$)$. However, the number of members 
again went down slightly in 2009. In the meantime there is a more positive trend (see Part 5). The reason for this was that the number of new members was very low, due to the crisis (Roth, 2010). One of the most important tasks of the trade union is collective bargaining. However, in the changing world of labour the trade union has to find answers to new challenges.

In the last few years this process of modernization on the shop floor-level has become more important. The body that legally represents the employees of a company is the works council. Works councils are elected by all company employees for a period of four years. Their structure, rights and obligations are regulated by the Works Constitution Act (WCA). However, due to permanent company restructuring, works councils need a lot more knowledge and competences than in the past to ensure a powerful interest representation and to act on level terms with the management.

The campaign better not cheaper was started in November 2004 in North Rhine-Westphalia. It can be seen as the attempt by IG Metall to stop being defensive and to take the initiative for innovative better or high road-solutions. A basic condition for the implementation of this strategy is the coordinated decentralization of the collective bargaining policy of IG Metall (see Korflür et alii, 2010, Burkhard, Schlette, 2008, Haipeter, 2009). It allows temporary deviation from the regional collective agreements and enables bargaining processes in single companies. It was in February 2004 that IG Metall accepted for the first time that under particular conditions individual companies can deviate from the negotiated standard rates in terms of lower wages or longer working time in the case of a bad profit situation, financial reorganisation or important investments, if this helps to save or create employment (Pforzheim agreement, 2004). An important condition for agreeing to a deviation from the standard rate was that the company should provide a convincing concept for the future of the company and its employees and a realistic return to the standard rates. This concept can include investment in new machinery, professional training, activities to open up new markets or modifications to the production system. Therefore, works councils in the affected companies have to ratify that the strategy is realistic and sustainable. It is supported by the trade union and by external consultants, assigned by the trade union. The works councils also have to monitor management's adherence to the negotiated conditions in case of a deviation. In order to carry out these tasks the works council has to be able to understand the arguments of the management and to assess the extent to which they are implemented. Thus the challenge for works councils has become a lot more complex. 
Better not cheaper means that IG Metall demands and enforces better innovative processes together with the works councils and the employees to ensure employment and income in the future. At the same time cost-driven cheaper strategies resulting in disadvantages for the employees (e. g. loss of income, insecure or precarious employment) have to be avoided. ${ }^{2}$ The works councils together with the employees try to question management strategies in the companies, to find internal solutions and to demand alternative schemes. Works councils should not become (co-) managers but they should be in a position to question managers on future management strategies.

The basic elements of the Better not cheaper strategy are:

- Trade union members should be informed about all steps securing the future of the company so that they can participate and influence them, and increase their assertiveness and ability to participate in the processes of change.

- Sustainable concepts for the future should be forcefully demanded, existing or planned management strategies should be questioned at an early stage, and alternatives (better-concepts) should be developed with professional support.

- Disagreements with the management over better solutions should be resolved with pressure if necessary to produce perceptible positive results for the employees.

Against this background of complex challenges, works councils need various competences and skills for a precautionary negotiating policy aimed at participation in the processes of change. This means that trade unions have to contribute to the development of these competences and skills to support works councils with knowledge and advice.

This approach is gaining importance, largely due to the crisis. The challenge is to strengthen the perspectives of the better not cheaper approach against this background in order to promote innovative sustainable arrangements for industrial companies and their employees. In IG Metall workshops, works councils have pointed out that during the crisis in many companies decision processes about production systems, relocation, changes in staff policy, profit margins, investments and innovations are accelerating. The management often expects that in this situation the implementation of controversial or conflictprone concepts disadvantaging the employees will be easier because there is high

2 Between better and cheaper there is a wide range of different strategies and there may be grey areas in the inplant practices. In the international debate there is a distinction between the innovation-driven high-road and the cost-driven low-road strategies. Similarly the polarised terms better - cheaper are heuristically quite useful (see also similar debates about high-performance workplaces and social sustainability in work systems). 
pressure to solve problems. In this case works councils who are not close enough to their work force and cannot contribute convincing counter-strategies in the debate with management can easily be forced onto the defensive.

In fact many works councils were working at full capacity to deal with the consequences of the sharp decline in orders and the lack of work, especially at the beginning of the crisis in 2009. They had to work under pressure of time to get an overview of the situation in the company, to develop survival strategies for the crisis, to find the suitable blend between company policy and collective agreements, to organize short-time work and to avoid redundancies. Dealing with these problems left no time to develop alternative strategies. But even in times of crisis critical questions about the future development of the company have to be considered. For example, are industrial structures suitable for the future and are employment, good work and good income secure? This also requires early input from works councils and IG Metall in the development of strategies for the future of the company and in demanding new concepts with potential for success.

The relationship between innovation and trade unions is by no means without tension. This is quite obvious if we look at the history of the rationalization debate (see Rundnagel, 2004). It is why the emphasis on the capacity for innovation as a key factor in economic success always has to be connected to the need to find specific solutions and to avoid falling back on one best way.

Many works councils have already discovered that powerful arguments in favour of change do not necessarily lead to change and that such mainstream concepts as lean production and its numerous ramifications on the shop floor level can have various results which influence employment and working conditions quite differently (see Brödner, Latniak, 1999; Oehlke et alii, 2007).

The trade union played various roles in the crisis: for example, keeping in touch with policy makers at national and regional level, ensuring the trade union perspective was taken into account in policy design, negotiating with employers' organisations, organising the implementation of crisis policy and developing new concepts and methods for trade union actions. Trade unions, however, cannot make detailed analyses of specific situations in a company for the works councils. However, they can offer them continuous support. One of these offers of support is the project competenceEinnovation.nrw which is embedded in a network of IG Metall projects and activities (projects in NRW like Besser: Zukunft and consultancy by the so called Task Force-crisis intervention). The idea is that companies can get into trouble at all times, not only in times of crisis. The task force crisis intervention provides IG Metall with help both for early detection, 
and also if the employer is already in the middle of a crisis. Works councils can contact IG Metall, who will provide a consultancy service for three to five days, usually financed by the companies. A network of consultants was developed in 2010 and was financed by the ministry of work until March 2012 .

\section{Trade union support for works councils: the project 'Competence and Innovation. nrw'}

The project competenceEinnovation aims at empowering works councils to develop and achieve better solutions for the company and employees. It involves a massive learning process for the union itself. Over the whole period and with different subjects, scientists, works councils and trade unionists held intense dialogues on how to create new ways to deal with future challenges and on how to negotiate on a par with management. These dialogues took place at company and intercompany level and in thematic workshops and conferences. The main subjects were temporary work, relocation, internationalization and global sourcing, production systems and new approaches to innovation. An important part of all these dialogues was to discuss and question management strategies and to develop new perspectives in order to find alternative ways of dealing with these challenges in future. Besides the official agenda of this project, for four years there has been the unique opportunity to observe and take part in the internal debates and activities of the union during these difficult times.

At company level this approach demands greater employee participation (in order to use their knowhow) and also greater work council competence. This more proactive and formative role for works councils and employees should attract employees to unions and also help to avoid the loss of union members. Even if it is difficult to attract the more highly skilled employees for union membership, there are positive developments especially amongst the younger employees despite the crisis.

One of the basic assumptions of the project is that there is a wide range of important expertise from scientists and consultants that is relevant to the challenges at company level. They have to be made accessible and adapted to the different users and aims if they are to have any influence on future actions. This means that requirements and problems on the company level not only have to be identified but also communicated in a close dialogue with scientists, works councils and consultants. ${ }^{3}$ Another important assumption is that employees and

3 Some of these requirements are covered by work-oriented consultants. But there is still a demand for additional expertise, even though the methods of some consultants are sometimes criticized by works councils. 
works councils have a deep insight into company procedures which has to be used to question management strategies.

The issue is expressly not a one-way transfer of knowledge in which scientists pass on a definite knowledge inventory to works councils by classroom teaching. It is a dynamic dialogue between scientists and practitioners. ${ }^{4}$ Scientists are mainly seen to make three possible contributions (see Latniak, 2004)

+ Communication: Initializing and ensuring communication about an existing set of problems

- Clarification: Clarifying the problem

- Consensus/Conflict: Promoting a more rational method of dealing with consensus and conflict processes in the company.

The approach is based on an exchange in which partners are on a par with each other and works councils have the role of co-researching partners. The starting point is a fundamental openness about the situation in the company. This approach is in contrast to the strategies of external management-oriented consultants who bring to the company more or less completed concepts and solutions and who do not have to take responsibility for the processes that take place after they have finished their contract (see Schilling/Latniak, 2006). Works councils are part of the «real life» of companies. They are the experts on work practice at company level with all its contradictions, tensions and paradoxes. What's new in their approach to management is that works councils do not only call into question the results of management strategies concerning social effects or negative effects on job stability. They now challenge management strategies and ask if these «are really adequate to produce the economic results they are promising» (see Haipeter, 2011) or if there are alternatives. The important point is that works councils now question management strategies «in the economic frame and reference of management». Therefore management cannot ignore these questions.

Finding a complete solution to problems within a company cannot be the aim of a (limited) project. The aim must be to identify gaps in knowledge and problem issues and create the conditions for a sustainable application of conditions that help the dialogue to continue. In this respect, this project helps to organize the transfer of knowledge and create networks which enable an exchange based on

«Work-oriented consultancy reaches its limits where consultants have a narrow range of concepts and fall back on standardized concepts even in very specific situations» (see Wetzel, 2009:45, translation AV/GS).

4 Concerning the concept of dialogue conferences, see also Fricke (2005), admittedly with a different contextualisation with regard to contents.

5 The science/practice transfer problem is not new, of course. The triad communication - clarification -consensus and conflict' is well-known from the American debate about 'usability' especially of socio-scientific knowledge (see Naschold, 1984). 
experience and the consequential search for possible solutions. The dialogues initiated by the project are expected to have a snowball effect. Contacts initiated under this project, with works councils in or between companies and with scientists or consultants will hopefully continue in the future as a matter of course without support. To implement this, the results of our project - documented in industrial policy memoranda - will be integrated in trade union training seminars (e.g. issues such as temporary work, outsourcing, production systems, internationalization of companies and its impacts on the German headquarters, innovation and participation of employees).

In these subject-related dialogues, scientists do not just give something, they also get something back. This 'something' could be ideas for generating new research questions or a broader outlook especially in the case of researchers who usually have a more management-oriented approach. In general, intensive dialogue offers the chance for a deeper understanding of the conditions for the practical implementation of work-oriented concepts. This kind of research is one with the unions and not research on or for unions (see Huzzard, 2011).

In the following passages we want to give the reader an insight into the process steps of the project (see figure 1) and describe two examples of successful interventions. The starting point is the specific problems of works councils who have to rise to the challenges generated by the conflict between business strategies and political conditions. When the set of problems has been identified by a discussion process, the project team examines the state of research and identifies scientists who, due to their expert knowledge, can contribute to a solution to the problem.

Among the processes and instruments used by the project team and the local trade union services for works councils are internal and external consulting, dialogue events and workshops for the car component industry, mechanical engineering, industry reports, works council surveys and theme-related strategic support. Industry dialogues, for example, create opportunities to discuss strategic questions with works councils, representatives of the company and experts in a variety of industries. ${ }^{6}$ Works council surveys about the difficult situation in the car component industry and on the topic of relocation have been carried out and the results can be used by other interested works councils as background information. The results of the different dialogue conferences and workshops are summarized in theme-related strategic and procedural guidelines (industrial policy memoranda), which provide works councils with strategic orientation and

6 Reports have been written on some industries in North Rhine-Westphalia (for example, pipeline construction, mining, engineering and the lighting industry). These reports analyse the overall structure of the industries as well as market developments and trends and they point out options for action in the companies. 
convincing arguments for challenges at company level, especially on contentious questions like relocations, overuse of temporary agency workers, implementation of new production systems and the enforcing of global value added chains and its outcome for industrial work in Germany.

The support services for works councils outlined above are completed with various strategic and procedural guidelines and checklists. These should trigger dialogue in companies between all the relevant parties to start a mutual learning and development process. From this process the sustainability of a company and with it the preservation of jobs and the qualitative design of working conditions can be built up. The results of the project are used for the framework of the education program for the members and full-time officials of the IG Metall in the regions of North Rhine-Westphalia. This is to assure that the activities and results of the project are sustained.

Figure 1 shows the chronology of the process steps in the project:

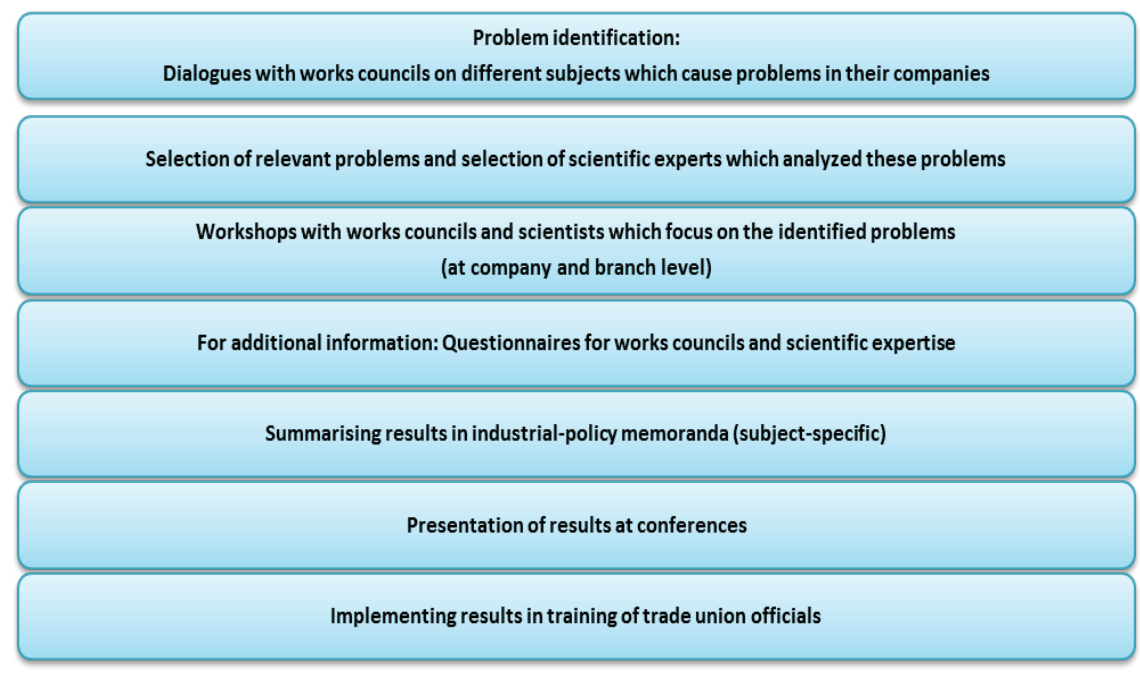

The project team edits scientific findings and experiences from within companies as background for producing industrial policy memoranda so that they are comprehensible for works councils and can be used to augment discussion at company level. For their daily work, works councils need

- Knowledge-based orientation: What is the current situation of their company? What are the managements' arguments? How can these arguments be evaluated?

- Standards for benchmarks between companies 
+ Recommendation for actions: What can be done in the given situation? How can support be organized?

Management tends to use arguments for the inevitable necessity of, for example, using temporary agency workers which can cause conflicts within the company. In many cases these reasons have not been sufficiently questioned. With the help of scientific knowledge on the one hand and knowledge-based experience on the other hand, works councils can find counter arguments to avoid these situations. This project should provide the works councils with a systemic filter for checking management's arguments. The dialogue will then show whether these arguments stand up to this scrutiny. The dialogue should commence with strategic questions and not with questions of cost. Experience shows that alternative strategies are often ignored because questions of costs arise too early in the process, which inhibits discussions about strategic aspects.

To give two examples for successful dialogue-based interventions:

\section{Subject «Outsourcing»}

Some years ago in negotiations with works councils the management of a company producing electronic household appliances agreed on a social compensation which included the outsourcing of a section that produced components. But finding a reliable supplier for the components proved to be difficult for the company. The works council took part in one of the project workshops which dealt with the outsourcing problem. It also obtained information about a possible consultancy financed by the union. After getting advice, the works council was able to question the outsourcing agreement. The works council asked the management to compare again the economic effects of outsourcing with the alternative of further in-house production. Both sides agreed to discuss the alternatives with experts from different sections in a work group, guided by the consultant. At least the experts from the company sections and management could be convinced that the in-house production of most of the components is cheaper than outsourcing. This business unit is still successful.

\section{Subject «Production System»}

In one part of a company (manufacturing) which produces woodworking machines, a new production system was successfully implemented. When introduced in another part of this company (construction), it didn't work. After discussions first with the works council and a union representative and then with the management the project organised a workshop in which both sides and scientists analysed the reasons for the suboptimal results in the construction 
sector. It became evident that a missing link was the lack in communication with the employees of that sector. The changes made in the construction area were not based on the experiences of the employees. Now the company will rethink the implementation and is developing a new suggestion system, where the ideas and improvements of employees are used to reorganise the construction sector.

The precondition for such a critical evaluation is the dialogue orientation of the stakeholders in the company. This project's approach requires that the stakeholders in the company can enter into a discussion and that they are willing to reconsider measures that have already been taken as well as accepting new measures for science-supported evaluation. Thus the situation in the company still has to be flexible. When the stakeholders' position regarding the implementation of a management decision without good reasons has hardened, another way of dealing with this confrontation has to be found. However, works councils need good arguments to convince the workforce also in conflict situations.

Previous case work at company level has shown that it is sensible to find out whether alliances between the works council and parts of the local management would be possible, to create new coalitions in order to save jobs at the old location. One lever is to question the usual concepts in the company by challenging the traditional ways of management (for example, comparing locations for a planned relocation with comparative concepts that also show the «hidden costs» of such measures).

This project wants to open as many different communication channels as possible: workshops at company level initiate intensive communication about the planned relocations that would not otherwise have been possible (e. g. chief executive, plant manager, sales persons, technicians, works council with trade union support, administrators). Workshops across company borders with works councils and scientists enable discussions about relevant topics of general importance. In addition, the structure for the argumentative traps that have been described earlier in this paper can be outlined for the industrial-policy memoranda.

The anticipated result of the solutions found in this process is to bring about a better balance between employer and employee interests, more appropriate solutions and greater commitment by the employees. However, one result of the project 'competence\&innovation' is that the IG Metall wants to continue dialogue with scientists and implement the North Rhine-Westphalia support strategy in all regions in Germany. 


\section{Conclusion}

After the crisis the need of works councils to develop strategies to stand up to future challenges is as important as during and before the crisis. They are aware that they are important actors in saving jobs and job quality and that, therefore, they have to cope with issues that are quite different from the traditional issues dealt with by works councils (such as income, working time etc.). They also need strategic competence in market and business developments if they are to question management strategies and be critical partners in negotiation with management. Only they can make sure that employees' interests are guaranteed in future changes within companies. However, a single, temporary trade-union project like competence $\mathcal{E}$ innovation. $n r w$ has limitations when long-term support for innovation reaches a larger scale. The IG Metall in North Rhine-Westphalia sees the project as part of the strategic development program 'Work 2020', which includes a campaign to improve collective bargaining coverage and the further development of the better not cheaper approach. The task is now to initiate more concrete change processes such as the high road or better strategies in companies. One important new element is the testing of the new method colleague coaching, which will lead to works councils advising each other. Another element is the so called task force crisis intervention, which started in the crisis and continued until March 2012. The task force provides a consultancy service that works councils can request if their company is either in a critical situation or they want to prevent just such a crisis. It is no surprise that the majority of consultancies (nearly a third) were requested by works councils in North Rhine-Westphalia. And the last but not the least of the challenges is to train the union employees. This work in progress is a giant learning process for the whole IG Metall organization and, as Turner $(2009: 310)$ points out, «offers unexpected promise for institutional revitalization» mainly because the new approach is organised around member mobilisation.

It looks likely that the new membership oriented strategy of IG Metall will benefit the union itself. Surprisingly, the number of trade union members did not decline in parallel with the number of lost jobs during the crisis as was the case during previous economic downturns. Between the start of the economic recovery at the end of 2009 and April 2011, more than 40,000 new members joined the union. In North Rhine-Westphalia, IG Metall was particularly successful in finding young employees as union members. Of course, because of the outflow this is not a real increase but it shows a new dynamic which encourages young people to join the union. 
However, the question is, can the trade unions use their improved image as a reliable partner to rise to future challenges and promote innovation? The answer has to be yes, but only if they deal with future challenges by continuously building up their competencies and knowledge. We have already mentioned that the union will continue to provide support. Issues connected with the crisis will be replaced by others which affect the future of the industry and industrial jobs: for example, new strategies will be required for a more sustainable use of energy resources or new technologies like electro mobility.

\section{References}

Abel, Jörg; Hirsch-Kreinsen, Hartmut; Ittermann, Peter (2009). «Made simple in Germany?» WSI-Mitteilungen 62 (11): 579-585.

Arbeitgeber.nrw (2009). Jahresbericht 2008/2009. Landesvereinigung der Arbeitgeberverbände Nordrhein-Westfalen e.V. Düsseldorf.

Blume, Lorenz; Gerstlberger, Wolfgang (2007). «Determinanten betrieblicher Innovation. Partizipation von Beschäftigten als vernachlässigter Einflussfaktor». Industrielle Beziehungen 14 (3): 223-244.

Bosch, Gerhard (2009). «Perspektiven einer nachhaltigen Industriepolitik. Gegenblende». Das gewerkschaftliche Online-Debattenmagazin, 1.

Brödner, Peter; Latniak, Erich (1999). «Der lange Weg zur «High Road»Neue Untersuchungsergebnisse zu organisatorischen Veränderungen im Unternehmen». In Institut Arbeit und Technik (eds.), IAT-Jahrbuch 1999/2000, Gelsenkirchen: 113-134.

Burkhard, Oliver; Schlette, Marc (2008). «Tarifverträge und Berater Neue Handlungsfelder für Arbeitnehmerinteressen». In Klaus Kost (ed.) (2008), Beratung anders. Consulting für Betriebsräte und Gewerkschaften, Marburg: 59-71.

Fricke, Werner (2005). «Das Modell der Dialogkonferenz zur Vernetzung von Wissenschaftlern und Gewerkschaftern als Arbeitskonzept für den Hattinger Kreis». Publications of the Hattinger Kreis in the context of the project «Organisationslernen in Gewerkschaften». URL: <http://www. hattingen.uni-oldenburg.de/19211.html> [22.07.2011].

Goudswand, Anneke; Oeji, Peter; Brugman, Tony; de Jong, Tanja (2009). Good practice guide to internal flexibility policies in companies. European Foundation for the Improvement of Living and Working conditions. $<$ http://www.eurofound.europa.eu/pubdocs/2009/19/en/1/EF0919EN. pdf $>$ [22.07.2011]. 
Haipeter, Thomas (2009). «Kontrollierte Dezentralisierung? Abweichende Tarifvereinbarungen in der Metall- und Elektroindustrie», Industrielle Beziebungen, 16 (3): 232-253.

Haipeter, Thomas (2011). «Better not cheaper. A German Trade Union Campaign and the problems of unions revitalization» (conference paper.)

Huzzard, Tony (2011). «Labour Process Analysis, Performativity and the Trade Unions: Towards an Action Research Agenda». 29 th Annual International Labour Process Conference Leeds University Business School, UK, 5th to $7^{\text {th }}$ April 2011.

ILO (2011). Safeguarding jobs in times of crisis - Lessons from the German experience. Dietz, Martin, Stops, Michael, Walwei, Ulrich Discussion paper. International Labour Organization. International Institute for Labour Studies. Geneva.

Iwer, Frank; Wagner, Hilde (2005)• «Grenzen der Vermarktlichung. Elemente einer aktivierenden Arbeits-, Betriebs- und Tarifpolitik». In DetJe, Richard et alii (eds.), Hamburg: 112-124.

Jirjahn, Uwe (2006). «Ökonomische Wirkungen der Mitbestimmung in Deutschland». Sozialer Fortschritt 55 (9), 215-226.

Kirner, Eva; Weissfloch, Ute; JäGer, Angela (2010). «Beteiligungsorientierte Organisation und Innovation». WSI Mitteilungen 63 (2), 87-94.

Kleiner, Matthias; Maevus, Frauke; Chatti, Sami (2007). Untersuchung zur Aktualisierung der Forschungsfelder für das Rahmenkonzept „Forschung für die Produktion von morgen«. Abschlussbericht, Band 2, gefördert vom Bundesministerium für Bildung und Forschung. Institut für Umformtechnik und Leichtbau, Universität Dortmund, Juni 2007.

Korflür, Inger; Nettelstroth, Wolfgang; Schilling, Gabi; Schlette, Marc; VAnselow, Achim (2010). ««Besser statt billiger» im Betrieb». WSIMitteilungen 63 (2): 109-112.

KriegesmanN, Bernd; Kley, Thomas; Kublik, Sebastian (2010). «Innovationstreiber betriebliche Mitbestimmung?» WSI-Mitteilungen 63 (2): $71-78$.

Kriegesmann, Bernd; Kley, Thomas (2012). Mitbestimmung als Innovationstreiber.Bestandsaufnahme,KonzepteundHandlungsperspektiven für Betriebsräte Berlin. edition sigma.

Latniak, Erich (2004). «Probleme und Perspektiven anwendungsorientierter Sozialwissenschaft im Spannungsfeld von Forschung und Organisationsberatung». In Dieter, Rehfeld (ed.) (2004), Arbeiten an der Quadratur des Kreises, München und Mering: 63-89. 
LehndorfF, Steffen (2003). «Soziale Nachhaltigkeit als Leitbild der Gestaltung von Arbeit und Arbeitszeit». In Institut Arbeit und Technik (ed.) (2003), IAT-Jahrbuch 2002/2003, Gelsenkirchen: 105-115.

Lesch, Hagen (2010). «Mitgliederentwicklung der Gewerkschaften. Bodenbildung». In: Gewerkschaftsspiegel. No. 1: 3.

MWEBWV (2011). Wirtschaftsbericht 2011. Ministerium für Wirtschaft, Energie, Bauen, Wohnen und Verkehr des Landes Nordrhein-Westfalen. Düsseldorf.

Naschold, Frieder (1984). «Was kann Industriesoziologie leisten?» In Universität Bielefeld, Fakultät für Soziologie/Hoesch Rothe Erde-Schmiedag AG (eds.) (1984), Industriesoziologie zwischen Theorie und Praxis, Bielefeld: $89-101$.

OECD (2010). Economic Survey of Germany 2010. Paris: OECD.

Oehlke, Paul; Riegler, Claudius; Wuppermann, Dietmar; Zettel, Claudio (2007). «Why take the «high road» of innovation? Work-oriented innovation strategies in Europe». Work-in-net background paper. December 2007. Bonn.

Rотн, Eva (2010). Krise trifft die Gewerkschaften. In: Frankfurter Rundschau. 26.01.2010.

Rundnagel, Regine (2004). Innovation und Beschäftigung - Mitgestalten der Zukunft. Working paper 81 of the Hans-Böckler-Foundation. Düsseldorf.

Schilling, Gabi; Latniak, Erich (2006). «Betriebliche Grenzen der «Verbetrieblichung»: Erfahrungen bei der Einführung flexibler Arbeitszeitmodelle in kleinen und mittleren Unternehmen». In: LeHNDORFF, Steffen (ed.): Das Politische in der Arbeitspolitik: Ansatzpunkte für eine nachbaltige Arbeits- und Arbeitszeitgestaltung. Berlin: 99-126.

Schumann, Michael (2008). «Kampf um Rationalisierung - Suche nach neuer Übersichtlichkeit». WSI-Mitteilungen 61 (7):379-386.

Schwarz-Kocher, Martin et alii (2011). Interessenvertretungen im Innovationsprozess. Der Einfluss von Mitbestimmung und Beschäftigtenbeteiligung auf betriebliche Innovationen. Berlin.

Stracke, Stefan; Nerdinger, Friedemann W. (2010). «Alles unter einen Hut bringen?» Rollen und Rollenkonflikte von Betriebsräten bei betrieblicher Innovation. Rostocker Beiträge zur Wirtschafts- und Organisationspsychologie. No. 3. University of Rostock.

Tietel, Erhard (2006). Konfrontation - Kooperation - Solidarität. Betriebsräte in der sozialen und emotionalen Zwickmüble. Berlin. 
Turner, Lowell (2009). «Institutions and Activism: Crisis and Opportunity for a German Labor Movement» in Decline, Industrial \& Labor Relations Review, Vol. 62, No. 3, article 2 URL: <http://digitalcommons.ilr.cornell. edu/ilrreviews/vol62/iss $3 / 2>$ (22.07.2011).

VDMA (2010). Maschinenbaukompetenz in NRW - Spitze in 2020. Produktion NRW, Cluster Maschinenbau/Produktionstechnik. Frankfurt am Main.

Wetzel, Dieter (2009). «Perspektiven der arbeitsorientierten Beratung Neue Handlungsfelder aus Sicht der Gewerkschaften». In: Klaus Kost (ed.) (2009), Beratung anders. Consulting für Betriebsräte und Gewerkschaften, Marburg: 28-47. 